\title{
FAS GENE POLYMORPHISMS ARE NOT ASSOCIATED WITH SYSTEMIC LUPUS ERYTHEMATOSUS, MULTIPLE SCLEROSIS AND HIV INFECTION
}

\author{
ISABELLA CASCINO*, CLARA BALLERINI ${ }^{\S}$, SANDRA AUDINO», GIANNI ROMBOLÀ, LUCA \\ MASSACESI", GUALTIERO COLOMBO ${ }^{\star}$, RAFFAELLA SCORZA SMERALDI ${ }^{\star}$, SANDRA \\ D'ALFONSO*, PATRICIA MOMIGLIANO RICHIARDI+, ROBERTO TOSI* AND GIOVINA \\ RUBERTI* \\ *Department of Immunobiology, Institute of Cell Biology, National Research Council, Roma, Italy \\ separtment of Neurological and Psychiatrical Sciences, University of Firenze, Italy

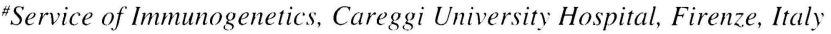
Institute of Internal Medicine, Infectious Diseases and Immunopathology, University of Milano - IRCCS Ospedale Maggiore of Milano

Department of Medical Sciences, University of Torino, Novara

KEY WORDS Human diseases Fas Polymorphisms

Fas (also known as APO-1 or CD95) triggers apoptosis (Nagata 1997; Chinnaiyan and Dixit. 1996; Fraser and Evan, 1996; Cleveland and Ihle, 1995). FasL and Fas receptor interactions play an important role in the regulation of the immune response and in the control of peripheral $\mathrm{B}$ and $\mathrm{T}$ cell survival that is critical to the maintenance of immune cell homeostasis (Nagata, 1997; Krammer et al., 1994; Nagata and Golstein, 1995). Fas is constitutively expressed in a wide range of non-immune cells (Nagata and Golstein, 1995). Furthermore Fas is inducible in some non lymphoid cell types upon appropriate stimulation e.g. IL-1 $\beta$ induces Fas expression in thyrocytes. Co-expression of functional Fas and FasL in Hashimoto's thyroiditis (HT) may contribute to thyroid destruction (Giordano et al., 1997). Alterations in Fas/FasL function may contribute to the pathogenesis of a number of human diseases, including cancer, autoimmune diseases and viral infections (Thompson et al., 1995).

We have identified two nucleotide substitutions in the Fas cDNA gene sequence. From their combination four haplotypes are expected, three of which have been observed in the normal Italian population (Fiucci and Ruberti, 1994). The functional significance of the observed nucleotide substitutions is nil because they do not lead to any amino acid change. However, considering the three detected haplotypes, their heterozygosity index (1-homozygote frequency) is 0.54 , which makes them sufficiently informative for genetic association studies (Fiucci and Ruberti, 1994). Thus, they may be useful markers for studying the possible involvement of Fas in autoimmune, lymphoproliferative or immunodeficiency diseases. Notably these

Correspondence to: Giovina Ruberti, Department of Immunobiology, Institute of Cell Biology, National Research Council, Roma, Italy. 
polymorphisms have been used (Fisher et al., 1995) to demonstrate the inheritance of Fas mutations in children with a rare human autoimmune lymphoprofilerative syndrome (ALPS).

We report a case-control association study of the above Fas polymorphism with the following three diseases: Multiple Sclerosis (MS), Systemic Lupus Erythematosus (SLE), and Human Immunodeficiency Virus (HIV) infection.

MS is considered as an autoimmune disease, but the underlying mechanisms of tissue injury and cell death are poorly understood. Possible mechanisms of cytotoxicity in human MS brain and the animal model, experimental allergic encephalomyelitis (EAE), have been studied and several candidate death effectors have been proposed (Martin et al., 1995). Recently Fas antigen expression has been investigated in MS lesions and it has been suggested that Fas-mediated signalling might contribute to immuno-mediated injury in MS (D’Souza et al., 1996; Dowling et al., 1996).

The identification of Fas and FasL mutations respectively in $l p r$ and gld mice which accelerate lupus-like autoimmunity (Nagata and Goldstein, 1995) and in children with ALPS (Fisher et al., 1995; Rieux-Laucat et al., 1995) suggest the possibility that genes involved in apoptosis may play a role in the genetic susceptibility to SLE.

Apoptosis of $\mathrm{T}$ lymphocytes has been proposed as a mechanism that plays an important role in the pathogenesis of HIV disease (Ameisen, 1992; Gougeon and Montagnier, 1993). An increased susceptibility to Fas-mediated apoptosis has been observed in $\mathrm{HIV}^{+}$individuals (Baumler et al., 1996; Katsikis et al., 1995; Li et al., 1995; Westendorp et al., 1995; Badley et al., 1996) suggesting that the Fas/FasL system plays an important role in the disease progression.

Three groups of patients, affected by MS, SLE and HIV diseases were typed for Fas polymorphisms. DNA samples were obtained from $62 \mathrm{MS}$ (according to the Poser diagnostic criteria, Poser et al., 1983); 98 SLE, $283 \mathrm{HIV}+$ patients as well as from 111 ethnically matched healthy controls. They were amplified by PCR and typed with digoxigenin-labelled (Dig Luminescent Detection Kit for Nucleic Acids; Boehringer, Mannheim, Germany) or ${ }^{32} \mathrm{P}$ labelled oligonucleotide probes for the polymorphic sites in exon 3 nucleotide position 416 (oligonucleotides: AGGGACTGCACA(orG)GTCAATGGG) and in exon 7 nucleotide position 836 (oligonucleotides: GAATCTCCAACC(orT)TTAAATCCT)(nucleotide numbering is according to Itoh et al., 1991). The primers for PCR were GR49: CTTTTTTCCTTGGGCAGGTG and GR50: AGACTCTTACCATGTCCTTCA for the position 416 polymorphism and GR19: AACATGCAGAAAGCACAGAA and GR52: ATGGAGCAAGACTCCATC for the position 836 polymorphism.

The three observed haplotypes are indicated as Fas-A, $-\mathrm{B}$ and $-\mathrm{C}$ based on the combinations of variations involving the third position of codon 416 (ACA to ACG) and codon 836 (ACC to ACT). (Table 1). Frequencies of patients and controls carrying the different haplotypes (Table 1) and the corresponding genotypes (Table 2) were compared by Chi-square test including Yates correction.

Genotypes could be unequivocally assigned even without family information because most individuals were homozygotes at one of the two positions. Out of the 554 individuals typed only five were double heterozygotes with ambiguous genotypes. They were compatible either with a B/C genotype or with the presence of a "D" haplotype (position $416 \mathrm{G}$, position $836 \mathrm{~T}$ ) which had not been detected in the normal population. Due to this uncertainty, since their families were not available, those cases (two SLE and three HIV+ patients) were excluded from the analysis. 
Table 1. Fas polymoprhisms in MS, SLE, HIV+ and controls*

\begin{tabular}{|c|c|c|c|c|c|c|}
\hline $\begin{array}{c}\text { Fas } \\
\text { haplotype }\end{array}$ & $\begin{array}{r}\text { Nuc } \\
\text { po } \\
416\end{array}$ & $\begin{array}{l}\text { leotide } \\
\text { sition } \\
836\end{array}$ & $\begin{array}{c}\text { MS n=62 } \\
n(\%)\end{array}$ & $\begin{array}{c}\text { SLE } n=98 \\
n(\%)\end{array}$ & $\begin{array}{c}\mathrm{HIV}+\mathrm{n}=283 \\
\mathrm{n}(\%)\end{array}$ & $\begin{array}{c}\text { Controls } \mathrm{n}=111 \\
\mathrm{n}(\%)\end{array}$ \\
\hline A & A & $\mathrm{C}$ & $51(82.2)$ & 93 (94.9) & $259(91.5)$ & $101(91.0)$ \\
\hline B & G & $\mathrm{C}$ & $1(1.6)$ & $8(8.2)$ & $20(7.1)$ & $10(9.0)$ \\
\hline $\mathrm{C}$ & $\mathrm{A}$ & $\mathrm{T}$ & $29(46.8)$ & $48(49.0)$ & $134(47.3)$ & $52(46.8)$ \\
\hline
\end{tabular}

* Figures represent numbers (percentages) of individuals carrying a given haplotype. For all comparisons the $\mathrm{P}$ values were not significant.

Table 2. Distribution of Fas genotypes in MS, SLE, HIV+ and controls

\begin{tabular}{lcccc}
\hline $\begin{array}{c}\text { Fas } \\
\text { genotype }\end{array}$ & $\begin{array}{c}\text { MS n=62 } \\
\mathrm{n}(\%)\end{array}$ & $\begin{array}{c}\text { SLE } \mathrm{n}=98 \\
\mathrm{n}(\%)\end{array}$ & $\begin{array}{c}\mathrm{HIV}+\mathrm{n}=283 \\
\mathrm{n}(\%)\end{array}$ & $\begin{array}{c}\text { Controls } \mathrm{n}=111 \\
\mathrm{n}(\%)\end{array}$ \\
\hline $\mathrm{A} / \mathrm{A}$ & $32(51.6)$ & $42(42.9)$ & $129(45.6)$ & $49(44.1)$ \\
$\mathrm{A} / \mathrm{B}$ & $1(1.6)$ & $8(8.2)$ & $17(6.0)$ & $10(9.0)$ \\
$\mathrm{A} / \mathrm{C}$ & $18(29.1)$ & $43(43.8)$ & $113(39.9)$ & $42(37.8)$ \\
$\mathrm{C} / \mathrm{C}$ & $11(17.7)$ & $5(5.1)$ & $21(7.4)$ & $10(9.0)$ \\
$\mathrm{B} / \mathrm{B}$ & 0 & 0 & $3(1.1)$ & 0 \\
$\mathrm{~B} / \mathrm{C}$ & 0 & $*$ & $*$ & 0 \\
\hline
\end{tabular}

For all comparisons the $\mathrm{P}$ values were not significant.

*The B/C genotype was not unequivocally attributable (see text).

Within each group of patients and controls the genotype distribution did not deviate significantly from the Hardy-Weinberg equilibrium. Both haplotype and genotype frequencies were similar in patients and controls. No significant differences were observed when the homosexual and drug user $\mathrm{HIV}^{+}$patients were considered separately. SLE is the most clinically and serologically diverse of the autoimmune connective tissue diseases, thus the Fas haplotype and genotype frequencies were also analyzed in relationship to patients clinical and immunologic findings. However no significant differences were observed in those subgroups (data not shown).

The participation of the Fas/FasL system as such in the pathogenetic mechanisms of the diseases is not touched by the present study, which pertain to the relevance of the Fas gene polymorphisms. More precisely the data show that Fas polymorphic functional variations that may be transmitted in linkage disequilibrium with the tested intragenic "silent" variations either do not exist or do not confer a differential susceptibility to the three diseases. Another possibility is that some infrequent Fas mutations may be responsible for particular disease subsets but do not show up in a general association study. The power of detecting a true association by linkage disequilibrium is known to 
depend heavily on the similarity of the population frequency of the so-called aetiologic mutation and that of the marker with which it associates (Muller-Myhsok and Abel, 1997). Thus the effect of an infrequent disease-associated variation would be detected in our study only if it happened to be associated with the rarest allele $\mathrm{B}$, but not with the two frequent $\mathrm{A}$ and $\mathrm{C}$ alleles. Consequently, the data we present should not discourage the search for rare Fas mutations in particular disease subgroups where there may be reason to suspect more specifically a Fas involvement.

Another possibility to be tested is the association with polymorphisms of genes that regulate Fas expression such as lymphokines, e.g. IL-1 $\beta$ and TNF $\alpha$. In addition it might be of interest to search for polymorphic variations in the FasL gene as well as in view of a test of possible genetic association. In fact, increased expression of FasL has recently been found in MS lesions (D'Souza et al., 1996) and a FasL gene mutation has been related to a lymphoproliferative disease (Wu et al., 1996).

\section{ACKNOWLEDGEMENTS}

We are grateful to L. Nisticò for stimulating discussions and E. Lancia and I. Pauselli for the technical help. This work was supported in part by grants from Italian National Institute of Health, AIDS (N. 9403-98) and Multiple Sclerosis (N. 34); from Telethon (E 162) and from Associazione Italiana Sclerosi Multiple (AISM).

\section{REFERENCES}

Ameisen, J.C. (1992). Programmed cell death and AIDS: from hypothesis to experiment. Immunol. Today, 13, 388-391.

Badley, D.B., McElhinny, J.A., Leibson, P.J., Lynch, D.H., Alderson, M.R., Paya, C.V. (1996). Upregulation of Fas Ligand expression by Human Immunodeficiency Virus in human macrophages mediates apoptosis of uninfected T lymphocytes. J. Immunol., 70, 199-206.

Baumler, C.B., Bohler, T., Herr, I., Benner, A., Krammer, P.H., Debatin, K.-M. (1996). Activation of the CD95 (APO-1/Fas) system in T cells from human immunodeficiency virus type-1infected children. Blood, 88, 1741-1746.

Chinnaiyan, A.M., Dixit, V.M. (1996). The cell-death machine. Curr. Biol., 6, 555-562.

Cleveland, J.L., Ihle, J.N. (1995). Contenders in FasL/TNF Death signalling. Cell, 81, 479-482.

Dowling, P., Shang, G., Raval, S., Menonna, J., Cook, S., Husar, W. (1996). Involvement of the CD95 (APO-1/Fas) receptor/ligand system in multiple sclerosis brain. J. Exp. Med., 184, 1513-1518.

D’Souza, S.D., Bonetti, B., Balasingam, V., Cashman, N.R., Barker, P.A., Troutt, A.B., Raine, C.S., Antel, J.P. (1996). Multiple sclerosis: Fas signalling in oligodendrocyte cell death. J. Exp. Med., 184, 2361-2370.

Fisher, G.H., Rosenberg, F.J., Straus, S.E., Dale, J.K., Middelton, L.A., Lin, A.Y., Strober, W., Lenardo, M.J., Puck, J.M. (1995). Dominant interfering Fas gene mutations impair apoptosis in a human autoimmune lymphoproliferative syndrome. Cell, 81, 935-946.

Fiucci, G., Ruberti, G. (1994). Detection of polymorphisms within the FAS cDNA gene sequence by GC-clamp denaturing gradient gel electrophoresis. Immunogenetics, 39, 437-439.

Fraser, A., Evan, G. (1996). A license to kill. Cell, 85, 781-784.

Giordano, C., Stassi, G., De Maria, R., Todaro, M., Richiusa, P., Papoff, G., Ruberti, G., Bagnasco, M., Testi, R., Galluzzi, A. (1997). Potential involvement of Fas and its Ligand in the pathogenesis of Hashimoto's Thyroiditis. Science, 275, 960-963.

Gourgeon, M.L., Montagnier, L. (1993). Apoptosis in AIDS. Science, 260, 1269-1270.

Itoh, N., Yonehara, S., Ishii, A., Yonehara, M., Mizushima, S., Sameshima, M., Hase, A., Seto, Y., Nagata, S. (1991). The polypeptide encoded by the cDNA for human cell surface antigen 
Fas can mediate apoptosis. Cell, 66, 233-243.

Katsikis, P.D., Wunderlich, E.S., Smith, C.A., Herzenberg, L.A., Herzenberg, LA. (1995). Fas antigen stimulation induces marked apoptosis of T lymphocytes in human immunodeficiency virus infected individuals. J. Exp. Med., 181, 2029-2036.

Krammer, P.H., Dhein, Y., Valczak, H., Behrmann, I., Mariani, S., Matiba, B., Fath, M., Daniel, P.T., Knipping, E., Westendorp, M.O., Stricker, K., Baumler, C., Hellbardt, S., Germer, M., Peter, M.E., Debatin, K.-M. (1994). The role of APO-1 mediated apoptosis in the immune system. Immunol. Rev., 142, 175-191.

Li, C.J., Friedman, D.J., Wang, C., Metelev, V. Pardee, A.B. (1995). Induction of Apoptosis in uninfected lymphocytes by HIV-1 Tat protein. Science, 268, 429-431.

Martin, R., MacFarland, H. (1995). Immunological aspects of experimental allergic encephalomyelitis and multiple sclerosis. Crit. Rev. Clin. Lab. Sci., 32, 121-182.

Muller-Myhsok, B., Abel, L. (1997). Genetic analysis of complex diseases. Science, 275, $1328-$ 1329.

Nagata, S., Golstein, P. (1995). The Fas death factor. Science, 267, 1449-1456.

Nagata, S. (1997). Apoptosis by death factor. Cell, 88, 355-365.

Poser, C., Paty, D.W., Sceinberg, L. (1983),. New diagnostic criteria for multiple sclerosis: guidelines for research protocols., Ann. Neurol., 13, 227-231.

Rieux-Laucat, F., Le Deist, F.. Hivroz, F.C., Roberts, I.A.G., Debatin, K.M., Fischer, A, de Villartay, J.P. (1995). Mutations in Fas associated with human lymphoproliferative syndrome and autoimmunity. Science, 268, 1347-1349.

Thompson, C.B. (1995). Apoptosis in the pathogenesis and treatment of disease. Science, 267, 1456-1462.

Westendorp, M.O., Frank, R., Ochsenbauer, C., Stricker, K., Dhein, J., Walczak, H., Debatin, K.-M., Krammer, P.H. (1995). Sensitization of T cells to CD95-mediated apoptosis by HIV1 Tat and gp 120. Nature, 375, 497-500.

Wu, J., Wilson, J., He, J., Xiang, L., Schur, P.H., Mountz, J.D. (1996). Fas ligand mutation in patients with systemic lupus erythematosus and lymphoproliferative disease. J. Clin. Invest., 98, 1107-1113. 


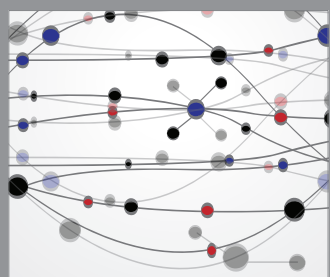

The Scientific World Journal
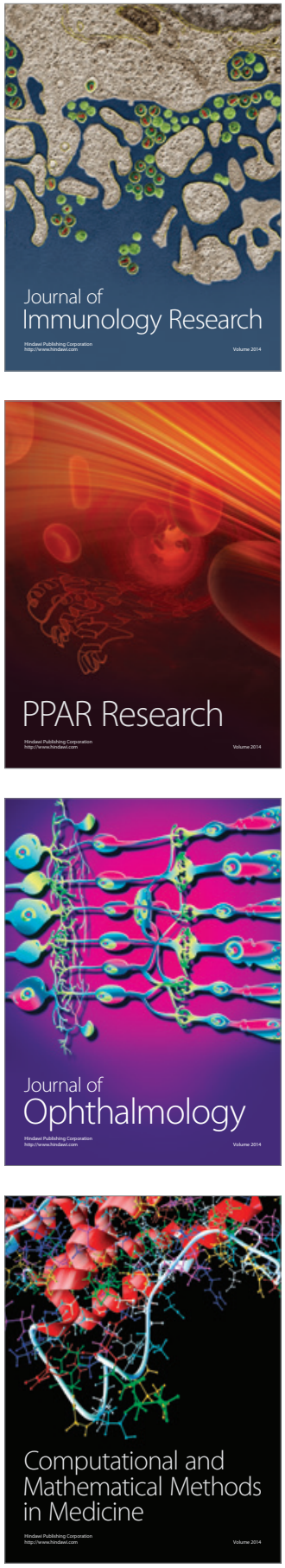

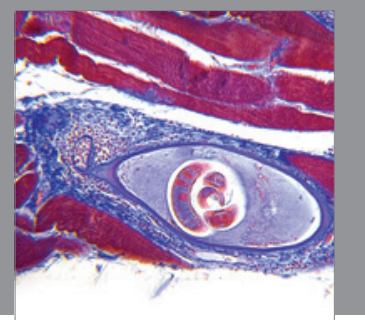

Gastroenterology

Research and Practice
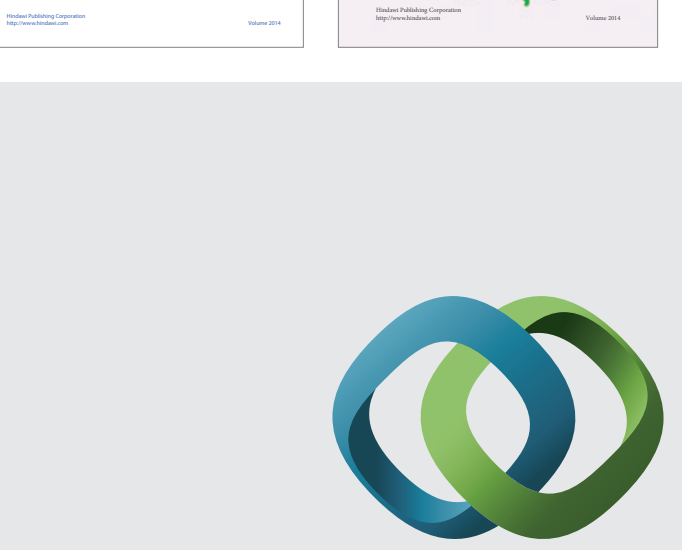

\section{Hindawi}

Submit your manuscripts at

http://www.hindawi.com
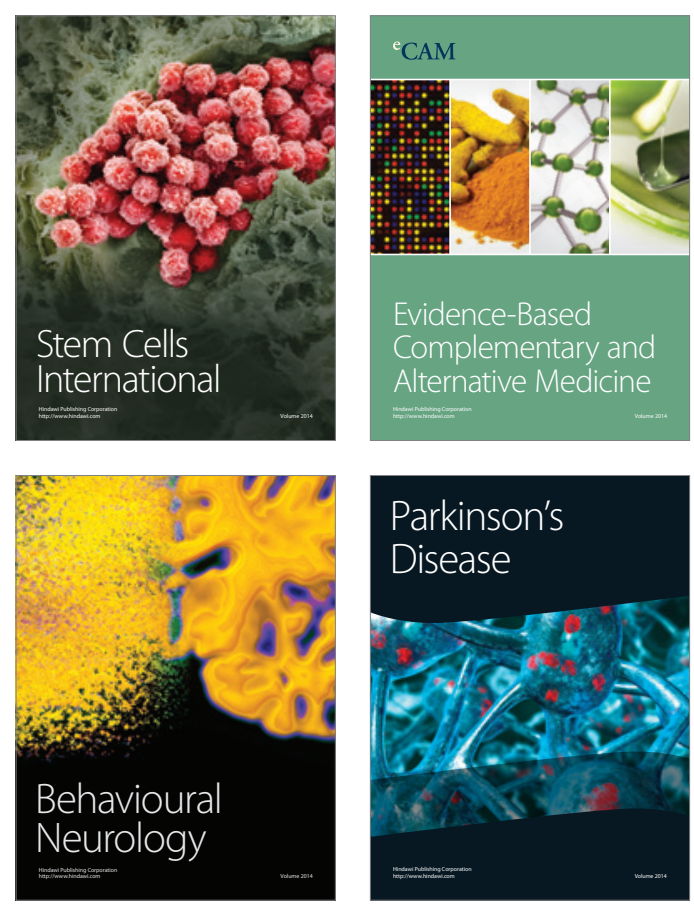

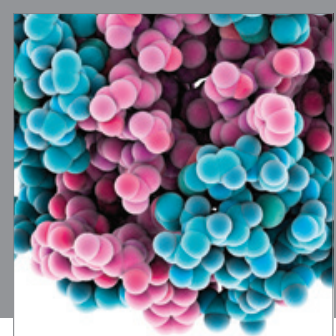

Journal of
Diabetes Research

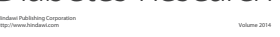

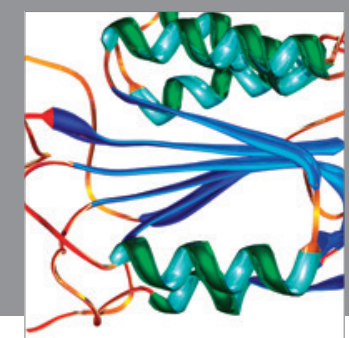

Disease Markers
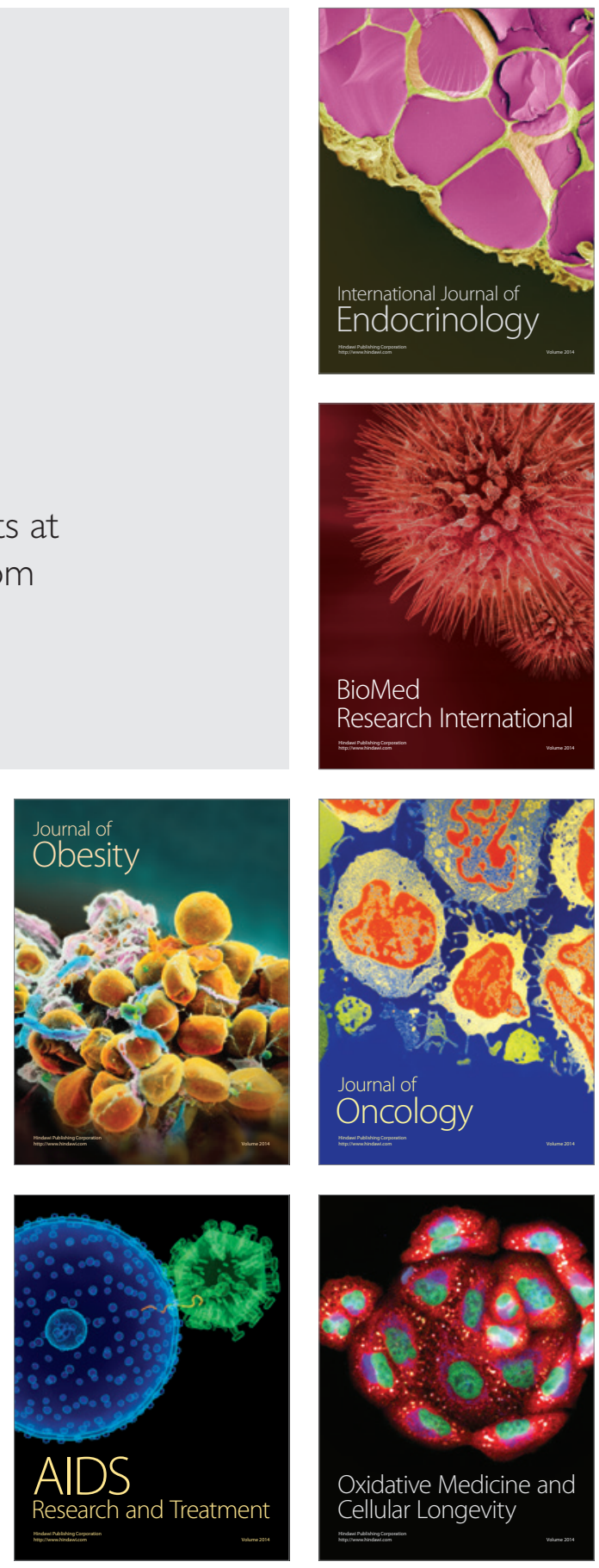